\title{
Pengaruh Modular Object-Oriented Dynamic Learning Environment (Moodle) Terhadap Hasil Belajar Siswa Pada Materi Sistem Pencernaan Manusia di Kelas VII MTsN Cikatomas
}

\author{
Dani Ramdani \\ Universitas Siliwangi \\ E-mail: lumutkering@gmail.com
}

\begin{abstract}
The purpose of this research was to determine the influence of Modular Object-Oriented Dynamic Learning Environment (MOODLE) to student result learning outcomes in the human digestive system in $7^{\text {th }}$ grade MTs N Cikatomas. This research was conducted in September to November 2014 in MTs N Cikatomas Tasikmalaya. Research method used the true experimental with the population was from all classes on $7^{\text {th }}$ grade as many as 5 classes with the number of students as many as 186 students. The sample was used are 2 classes that selected by the cluster random sampling technique. To measure learning outcomes used 40 questions learning outcomes instrument. Technique of analyzing the data in this research using t-test with significant level $a=$ 0,05. Based on data analysis and bypothesis testing be concluded that there is influence of Modular Object-Oriented Dynamic Learning Environment (MOODLE) to student result learning outcomes in the human digestive system in $7^{\text {th }}$ grade MTs N Cikatomas.
\end{abstract}

Keywords: Modular Object-Oriented Dynamic Learning Environment (MOODLE), Learning Outcomes, Human Digestive System

\section{Pendahuluan}

I lmu Pengetahuan dan Teknologi (IPTEK) semakin lama semakin berkembang pesat. Perkembangan iptek ini tentunya memiliki dampak positif dan negatif bagi kehidupan manusia. Ilmu pengetahuan dan teknologi merupakan dua hal yang tidak dapat dipisahkan, keduanya akan saling menunjang. Perkembangan teknologi juga akan mampu meningkatkan perkembangan ilmu pengetahuan. Perkembangan teknologi telah memiau munculnya persaingan dalam berbagai bidang, salah satunya dalam bidang pendidikan.

Kehadiran Teknologi Informasi dan Komunikasi (TIK) dalam pembelajaran merupakan tantangan tersendiri bagi dunia pendidikan. Tuntutan dalam globalisasi, pendidikan telah hadir di depan mata. Berbagai perangkat komputer beserta koneksinya dapat menghantarkan peserta belajar secara cepat dan akurat apabila dimanfaatkan secara benar dan tepat. Teknologi menyediakan berbagai alternatif yang dapat digunakan untuk menyampaikan materi kepada peserta didik. Penggunaan media yang disediakan teknologi informasi merupakan salah satu usaha pengembangan kualitas pendidikan.

Menurut Purwanto (1997:1) "Pendidikan merupakan suatu proses komunikasi dan transfer informasi dari pendidik kepada peserta didik yang berisi informasi pendidikan, yang memiliki unsur pendidikan sebagai sumber informasi, sebagai media sarana penyampaian ide, gagasan, materi pendidikan serta peserta didik itu sendiri'”.

Proses pembelajaran akan menghasilkan hasil belajar. Hasil belajar inilah yang dijadikan kriteria dalam pencapaian tujuan pendidikan. Menurut Djamarah, Syaiful Bahri dan Aswan 
Zain (1997:119) "Hasil belajar merupakan kemampuan nyata yang dicapai seorang individu atau siswa setelah mengikuti kegiatan belajar yang proses pengukurannya menggunakan tes".

Hasil belajar peserta didik salah satunya dipengaruhi oleh media pembelajaran. Menurut Gerlach dan Ely dalam Asyar, H. Rayandara (2011:6) "Media pembelajaran memiliki cakupan yang luas, yaitu termasuk manusia, materi atau kajian yang membangun suatu kondisi yang membuat peserta didik mampu memeperoleh pengetahuan, keterampilan atau sikap". Media pembelajaran mencakup semua sumber yang diperlukan untuk melakukan komunikasi dalam pembelajaran, sehingga bentuknya bisa perangkat keras (hardware), seperti komputer, televisi, proyektor, dan perangkat lunak (software) yang digunakan pada perangkat keras tersebut. Media pembelajaran yang berkaitan dengan pemanfaatan perkembangan teknologi adalah Learning Management System (LMS).

Menurut Wahono (2008:1) Learning Management System (LMS) "Adalah aplikasi perangkat lunak untuk dokumentasi, administrasi, pelacakan, pelaporan program pelatihan, kelas dan kegiatan online, program pembelajaran elektronik (e-learning program), dan isi pelatihan". Selanjutnya Wahono (2008:1) memberikan diri-ciri sebuah LMS yang kuat harus bisa melakukan hal berikut:
a. Memusatkan dan mengotomatisasi administrasi;
b. Menggunakan layanan "self-service" dan "self- guided";

c. Mengumpulkan dan menyampaikan konten pembelajaran dengan cepat;

d. Mengkonsolidasikan inisiatif pelatihan pada platform berbasis "web scalable";

e. Mendukung portabilitas dan standar;

f. Meresonalisasi isi dan memungkinkan penggunaan kembali pengetahuan.

Secara sederhana dapat dipahami bahwa Learning Management System (LMS) ini terdiri dari aplikasi yang dapat digunakan sebagai alat bantu dalam kegiatan pendidikan. Salah satu aplikasi alternatif Learning Management System (LMS) yang bisa digunakan adalah Modular Object Oriented Dynamic Learning Environment (MOODLE).

MOODLE merupakan sebuah nama untuk sebuah program aplikasi yang dapat merubah sebuah media pembelajaran kedalam bentuk website. Aplikasi ini memungkinkan peserta didik untuk masuk ke dalam "ruang kelas" digital untuk mengakses materi-materi pembelajaran. Dengan menggunakan MOODLE, kita dapat membuat materi pembelajaran, kuis, jurnal elektronik dan lain-lain. Menurut Renaldo (2009:1) peran pengajar dalam sistem MOODLE ini antara lain: "Berhubungan dengan muridmurid secara perorangan untuk memahami kebutuhan belajar mereka dan memoderatori diskusi serta aktivitas yang mengarahkan murid untuk mencapai tujuan belajar dari kelas tersebut".

Pemrograman yang digunakan untuk membangun LMS MOODLE adalah bahasa PHP dan menggunakan database MySQL. Untuk bisa mejalankan sistem website tersebut, kita memerlukan server yang bisa membaca pemrograman PHP-MySQL sehingga bisa menampilkannya pada browser. Mengingat hal tersebut maka untuk menjalankan MOODLE kita membutuhkan space bosting pada sebuah webserver. Untuk memenuhinya kita bisa membeli secara online di beberapa situs penyedia webhosting.

Seiring dengan perkembangannya di dunia maya bermunaulan situs-situs penyedia jasa webhosting secara gratis. Namun demikian meskipun kita bisa mendapatkan bosting dan domain atau akses internet gratis sekalipun, kita juga akan kesulitan dalam hal waktu dan hasil yang tidak maksimal. Sebab kita akan terganggu dengan akses internet yang mungkin masih lambat, belum lagi kalau putus nyambung putus nyambung. 
Akhirnya, localhost menjadi solusinya. Kita akan menjadikan komputer kita menjadi local server yang bisa bekerja hampir sama dengan server yang saya sebut di atas. Sama dalam hal menjalankan pemrograman PHP-MySQL yang digunakan untuk membangun LMS MOODLE. Dikatakan local karena hanya sebatas komputer dalam jaringan local kita saja yang bisa maengaksesnya. Amri (2011:1) "Dengan menjadikannya sebagai local server, maka kita akan menghostingkan file website kita pada komputer tersebut dan menjadikannya sebagai tempat membangun website kita". Sistem hosting tersebutlah yang dinamakan LOCALHOST. Intinya, kita menjadikan komputer kita menjadi localserver, kemudian menghostingkan website kita didalamnya (localhost). Dengan menjadikan komputer kita sebagai localserver, kita dapat bekerja secara offline tanpa harus takut menghadapi masalah biaya, waktu, kota internet dan kenyamanan.

Berdasarkan hasil wawancara yang dilakukan pada bulan Desember 2013 dengan guru pengampu utama pelajaran IPA kelas VII di MTs N Cikatomas diketahui bahwa nilai hasil ulangan materi pada konsep Sistem Pencernaan Manusia kurang memuaskan. Konsep ini diangap sulit diajarkan karena menjelaskan struktur dan proses yang abstrak selain itu proses pembelajarannya masih menggunakan metode konvensional. Maka diperlukan suatu pembelajaran yang berbeda dan memuat suatu usaha nyata untuk mempermudah pembelajaran yang bersifat abstrak sehingga dapat lebih kongkrit atau nyata.

\section{Metode}

Metode penelitian yang digunakan adalah true experiment. Populasi dalam penelitian ini adalah seluruh siswa kelas VII MTs N Cikatomas tahun ajaran 2013/2014 sebanyak 5 kelas. Sampel yang digunakan dalam penelitian ini diambil dengan menggunakan teknik duster random sampling sebanyak 2 kelas yaitu kelas VII A sebagai kelas eksperimen dan VII C sebagai kelas kontrol. Untuk mengukur hasil belajar digunakan instrument berupa tes hasil belajar sebanyak 40 soal pilihan ganda soal mengenai materi sistem pencernaan pada manusia dengan 4 pilihan jawaban. Soal yang diberikan telah teruji validitas dan reliabilitasnya.

Desain penenelitian yang digunakan dalam penelitian ini adalah pretest-posttest control group. Peneliti memberikan pretest terlebih dahulu kepada peserta didik sebelum dilakukan pembelajaran dan memberikan posttest setelah pembelajaran. Dengan demikian hasilnya dapat diketahui dengan akurat, karena peneliti dapat membandingkan sebelum diberikan pengajaran dan sesudah dilakukan pengajaran.

\section{Hasil}

Berdasarkan penelitian yang telah dilakukan di VII MTsN Cikatomas diperoleh data sebagai berikut: 
Tabel.1

Rata-rata Skor Pretest, Posttes dan N-gain di Kelas Eksperimen dan Kelas

\begin{tabular}{|c|c|c|c|}
\hline Kelas & Pre test & Post test & $\mathbf{N}$-gain \\
\hline 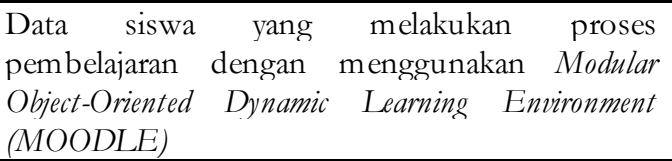 & 21,15 & 30,79 & 0,52 \\
\hline $\begin{array}{l}\text { Data siswa yang melakukan } \\
\text { pembelajaran tidak menggunakan }\end{array} \begin{array}{l}\text { Modular } \\
\text { Object-Oriented Dynamic Learning Environment } \\
\text { (MOODLE) }\end{array}$ & 19,91 & 25,18 & 0,27 \\
\hline
\end{tabular}

\section{Kontrol}

Berdasarkan tabel 1 data hasil penelitian menunjukkan bahwa rata- rata skor pretest kelas eksperimen adalah 21,15 rata-rata skor posttest adalah 30,79 dan N-gain 0,52. Sedangkan rata-rata skor pretest kelas kontrol adalah 19,91 rata-rata skor posttest adalah 25,18 dan N-gain 0,27.
Untuk menguji kenormalan data digunakan uji $\chi^{2}$. Berdasarkan hasil analisis dapat disimpulkan bahwa ke-enam data berasal dari populasi yang berdistribusi normal sebagaimana ditunjukkan pada tabel 2 sebagai berikut:

Tabel.2.

Ringkasan Hasil Uji Normalitas

\begin{tabular}{|l|c|c|l|l|}
\hline \multicolumn{1}{|c|}{ Data } & $\mathbf{2}_{\text {hitung }}$ & $\mathbf{2}_{\text {tabel }}$ & \multicolumn{1}{|c|}{ Hasil analisis } & $\begin{array}{c}\text { Kesimpulan } \\
\text { Analisis }\end{array}$ \\
\hline Pre-test kelas eksperimen & 2,295 & 7,81 & 2hitung $<2$ tabel & Tolak Ho \\
\hline Post-test kelas eksperimen & 2,681 & 7,81 & 2hitung $<2$ tabel & Tolak Ho \\
\hline -gain kelas eksperimen & 1,049 &, 81 & 2hitung $<2$ tabel & Tolak Ho \\
\hline Pre-test kelas kontrol & 1,283 & 7,81 & 2hitung $<2$ tabel & Tolak Ho \\
\hline Post-test kelas kontrol & 2,179 & 7,81 & 2hitung $<2$ tabel & Tolak Ho \\
\hline N-gain kelas kontrol & 1,525 & 7,81 & 2hitung $<2$ tabel & Tolak Ho \\
\hline
\end{tabular}


Untuk mengetahui ke-enam data hasil tes belajar tersebut homogen atau tidak, dilakukan uji homogenitas dua varians dengan menggunakan Fmaksimum. dengan taraf nyata $\alpha=0,05$. Hasil analisis dari uji homogenitas tersebut dapat disimpulkan bahwa ketiga kelompok data tersebut variansnya homogen sebagai berikut:

Tabel 3. Ringkasan Hasil Uji Homogenitas

\begin{tabular}{|c|c|c|c|c|c|}
\hline Data & Fhitung & Ftabel & $\begin{array}{c}\text { Hasil } \\
\text { Analisis }\end{array}$ & Kesimpulan & $\begin{array}{c}\text { Kesimpulan } \\
\text { Analisis }\end{array}$ \\
\hline $\begin{array}{c}\text { Skor pretest } \\
\text { - postes } \\
\text { eksperimen }\end{array}$ & 1,25 & 1,81 & $\begin{array}{c}\text { F hitung }<\mathrm{F} \\
\text { tabel }\end{array}$ & Terima Ho & $\begin{array}{c}\text { Kedua varians } \\
\text { homogen }\end{array}$ \\
\hline $\begin{array}{c}\text { Skor pretest } \\
\text { - posttest } \\
\text { kontrol }\end{array}$ & 1,38 & 1,81 & $\begin{array}{c}\text { F hitung }<\mathrm{F} \\
\text { tabel }\end{array}$ & Terima Ho & $\begin{array}{c}\text { Kedua varians } \\
\text { homogen }\end{array}$ \\
\hline $\begin{array}{c}\text { N-gain } \\
\text { eksperimen } \\
\text { - N-gain } \\
\text { kontrol }\end{array}$ & 1,24 & 1,81 & $\begin{array}{c}\text { F hitung }<\mathrm{F} \\
\text { tabel }\end{array}$ & Terima Ho & $\begin{array}{c}\text { Kedua varians } \\
\text { homogen }\end{array}$ \\
\hline
\end{tabular}

Tabel 4. Ringkasan Hasil Uji t dependent

\begin{tabular}{|l|l|l|l|l|l|}
\hline \multicolumn{1}{|c|}{ Data } & \multicolumn{1}{c|}{$\begin{array}{c}\mathbf{t} \\
\text { hitung }\end{array}$} & \multicolumn{1}{c|}{$\begin{array}{c}\text { H } \\
\text { tabel }\end{array}$} & \multicolumn{1}{c|}{$\begin{array}{c}\text { Hasil } \\
\text { Analisis }\end{array}$} & Kesimpulan & \multicolumn{1}{c|}{$\begin{array}{c}\text { Kesimpulan } \\
\text { Analisis }\end{array}$} \\
\hline $\begin{array}{l}\text { Pretest - } \\
\text { Postest } \\
\text { eksperimen } \\
\text { (Uji t } \\
\text { dependent) }\end{array}$ & $-17,53$ & 2,04 & $\begin{array}{l}\text { thitung }<- \\
\text { ttabel }\end{array}$ & Tolak Ho & $\begin{array}{l}\text { Ada peningkan } \\
\text { hasil belajar siswa } \\
\text { sebelum dan sesudah } \\
\text { proses pembelajaran }\end{array}$ \\
\hline $\begin{array}{l}\text { Pretest- } \\
\text { Posttest } \\
\text { Control (Uji } \\
\text { tependent) }\end{array}$ & $-11,46$ & 2,04 & $\begin{array}{l}\text { thitung }<- \\
\text { ttabel }\end{array}$ & Tolak Ho & $\begin{array}{l}\text { Ada peningkatan } \\
\text { hasil belajar siswa } \\
\text { sebelum dan sesudah } \\
\text { proses pembelajaran }\end{array}$ \\
\hline $\begin{array}{l}\text { N-gain } \\
\text { eksperimen - } \\
\text { N-gain } \\
\text { control (Uji t } \\
\text { independent) }\end{array}$ & 2,76 & 2,00 & $\begin{array}{l}\text { thitung }> \\
\text { ttabel }\end{array}$ & Tolak Ho & $\begin{array}{l}\text { Ada pengaruh } \\
\text { Modular Object- } \\
\text { Oriented Dynamic } \\
\text { Learning } \\
\text { Environment } \\
\text { (MOODLE) } \\
\text { terhadap hasil belajar } \\
\text { siswa pada Sistem } \\
\text { Pencernaan Manusia }\end{array}$ \\
\hline
\end{tabular}




\section{Pembahasan}

Berdasarkan pada hasil uji hipotesis menggunakan (uji t) thitung $=2,76$ dan ttabel $=2,00$ Simpulan analisisnya yaitu tolak Ho, yang artinya "Ada pengaruh Modular Object-Oriented Dynamic Learning Environment (MOODLE) terhadap hasil belajar siswa pada Sistem Pencernaan Manusia di kelas VII MTsN Cikatomas".

Kedua sampel penelitian diberikan perlakuan yang berbeda, perlakuaan yang diberikan pada kelas eksperimen adalah penggunaan Modular Object-Oriented Dynamic Learning Environment (MOODLE) pada materi sistem pencernaan pada manusia sedangkan di kelas kontrol diberikan perlakuan dengan menggunakan model pembelajaran konvensional.

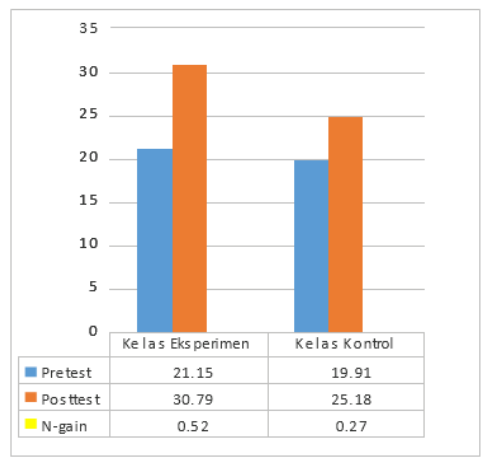

Gambar 1. Diagram perbedaan hasil perolehan skor kelas eksperimen dan kelas control (sumber: hasil pengolahan data)

Berdasarkan diagram di atas diketahui bahwa rata-rata $\mathrm{N}$-gain kelas eksperimen adalah 0,52 dengan kategori sedang, sedangkan rata-rata $\mathrm{N}$-gain kelas kontrol adalah 0,27 sehingga terlihat perbedaan yang signifikan. Perbedaan tersebut menunjukkan peningkatan hasil belajar siswa di kelas eksperimen lebih baik dari dibandingkan kelas kontrol. Skor hasil belajar siswa di kelas eksperimen memiliki skor rata-rata pretest 21,15 dan skor rata-rata posttest 30,79 sedangkan kelas kontrol memiliki skor rata-rata pretest 19,91 dan skor rata-rata posttest 25,18. Dilihat dari perbedaan skor rata-rata pretest kelas eksperimen dan kelas kontrol yang relatif kecil, menandakan bahwa pengetahuan awal siswa tentang materi sistem pencernaan pada manusia hampir sama dari kedua kelas, dengan pengetahuan yang hampir sama baik siswa di kelas eksperimen maupun di kelas kontrol mempunyai potensi yang sama pula dalam mendapatkan skor posttest. Namun, setelah diberikan perlakuan dikedua kelas terdapat perbedaan skor rata-rata posttest dimana skor rata-rata posttest kelas eksperimen lebih tinggi dari pada kelas kontrol, Hal ini menegaskan bahwa pembelajaran yang menggunakan Modular Object-Oriented Dynamic Learning Environment (MOODLE) dapat memotivasi siswa dalam belajar sehingga memberikan pengaruh terhadap hasil belajar siswa.

Media pembelajaran Modular Objectzriented Dynamic Learning Environment (MOODLE) memberikan kebebasan belajar sehingga tercipa satu interaksi virtual antara guru dengan siswa yang menyeluruh. Selain itu terbangun juga suasana pembelajar secara privat antara guru dan siswa sehingga siswa yang memiliki kesulitan bisa mengajukan pertanyaan secara khusus kepada guru. Kemudahan lainnya bagi siswa untuk melakukan interaksi dengan materi 
sehingga siswa dapat mengakses materi secara beulang-ulang sampai peserta didik merasa benar-benar menguasai materi.

Disamping itu penggunan media pembelajaran Modular Object-Oriented Dynamic Learning Environment (MOODLE) memberikan pengalaman lebih bagi siswa sehingga minat siswa kan pembelajar lebih meingkat.

Pengguanaan media pemebelajaran Modular Object-Oriented Dynamic Learning Environment (MOODLE) ini juga memberikan kesempatan bagi siswa untuk membentuk pemahaman mengenai suatu konsep atau peristiwa melalui rekayasa peristiwa yang dinilai abstrak atau rumit menjadi nyata dengan digantikan dengan simbol-simbol tertentu yang dinilai kongkrit sehingga proses yang terlalu lama bisa di persingkat, benda yang besar bisa di perkecil dan benda yang kecil bisa dperbesar sesuai dengan kebutuhan.

\section{Simpulan}

Berdasarkan hasil pengolahan data, analisis data dan pengujian hipotesis maka penulis berkesimpulan bahwa ada pengaruh Modular Object-Oriented Dynamic Learning Environment (MOODLE) terhadap hasil belajar siswa pada materi sistem pencernaan manusia di kelas VII MTs N Cikatomas.

\section{Saran}

Berdasarkan hasil penelitian yang telah dilakukan, maka penulis menyarankan: bagi guru yang akan melakukan pembelajaran dengan menggunakan Modular Object-Oriented Dynamic Learning Environment (MOODLE) disarankan masalah yang dikemu-kakan dalam pembelajaran adalah masalah nyata yang ada di sekitar sekolah maupun wilayah tempat tinggal peserta didik agar didapatkan pembelajaran bermakna yang akan membangkitkan minat serta aktivitas belajar peserta didik terhadap materi sehingga dapat melatih untuk dapat memecahkan masalah dengan berbagai pemikiran yang kreatif dan; bagi peneliti selanjutnya, disarankan untuk mecoba meneliti pengaruh penggunaan Modular Object-Oriented Dynamic Learning Environment (MOODLE) dengan materi yang lain. 
58 | Naturalistic

\section{Daftar Rujukan}

Amri. (2011). Cara Membuat Database MySQL localhost di XAMP. [online] tersedia di: http:/ / kentos.web.id/ cara-membuat-database-mysql-localhost-di-xampp/ (28/12/2011)

Asyhar, H. Ryandra. (2011). Kreatif Mengembangkan Media Pembelajaran. Jakarta. Garung Persada Pers.

Djamarah, Syaiful Bahri dan Aswan Zain.(1997). Strategi Belajar Mengajar. Jakarta: PT. Rineka Cipta.

Purwanto, Ngalim. (1997). Psikologi Pendidikan. Bandung: Remaja Rosdakarya.

Renaldo, Ferri. (2009). Moodle dan Fitur-fiturnya. [online] tersedia di: http://ilmukomputer.org/upcontents/ uploads/20099/02/ferri-fiturmoodle.pdf. (26/12/2011)

Wahono, R.S. (2008). Meluruskan salah kaprab tentang e-learning. [online] tersedia di: http://mnn.romisatriawahono.net/2008/meluruskan slab kaprah tentang e-learning/. (26/12/2011).ono, R.S. (2008). Memilib Sistem e-learning berbasis open source. [online] tersedia di: bttp:/ / mnn.romisatriawahono.net/2008/ memilih-sistem-elearning-berbasi-open-source/. (26/12/2011). 